\title{
APR 71966
}

TECHNICAL INTCRLMTION OIVISION

LIVERMORE
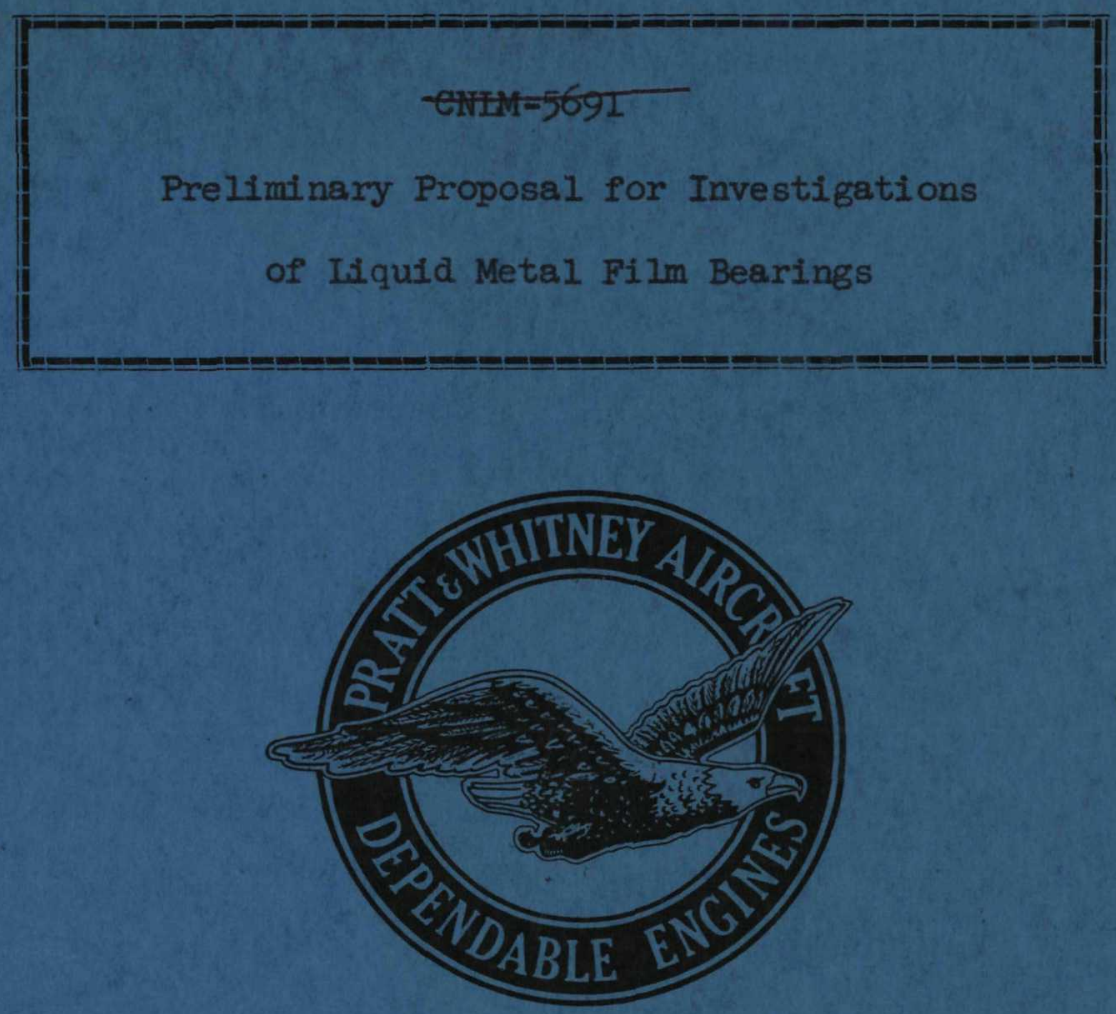

$\begin{array}{llllllllllllllllllll}P & R & A & T & \text { \& } & \text { W } & H & \text { I } & T & N & E & Y & A & \text { I } & R & C & R & A & F & T\end{array}$ DIVISION OF UNITED AIRCRAFT CORPORATION CANEL
MIDDLETOWN
CONNECTICUT 


\section{DISCLAIMER}

This report was prepared as an account of work sponsored by an agency of the United States Government. Neither the United States Government nor any agency Thereof, nor any of their employees, makes any warranty, express or implied, or assumes any legal liability or responsibility for the accuracy, completeness, or usefulness of any information, apparatus, product, or process disclosed, or represents that its use would not infringe privately owned rights. Reference herein to any specific commercial product, process, or service by trade name, trademark, manufacturer, or otherwise does not necessarily constitute or imply its endorsement, recommendation, or favoring by the United States Government or any agency thereof. The views and opinions of authors expressed herein do not necessarily state or reflect those of the United States Government or any agency thereof. 


\section{DISCLAIMER}

Portions of this document may be illegible in electronic image products. Images are produced from the best available original document. 


\section{LEGAL NOTICE}

This report was prepared as an account of Government sponsored work. Neither the United States, nor the Commission, nor any person acting on behalf of the Commission:

A. Makes any warranty or representation, expressed or implied, with respect to the accuracy, completeness, or usefulness of the information contained in this report, or that the use of any information, apparatus, method, or process disclosed in this report may not infringe privately owned rights; or

B. Assumes any liabilities with respect to the use of, or for damages resulting from the use of any information, apparatus, method, or process disclosed in this report.

As used in the above, "person acting on behalf of the Commission" includes any employee or contractor of the Commission, or employee of such contractor, to the extent that such employee or contractor of the Commission, or employee of such contractor prepares, disseminates, or provides access to, any information pursuant to his employment or contract with the Commission, or his employment with such contractor. 

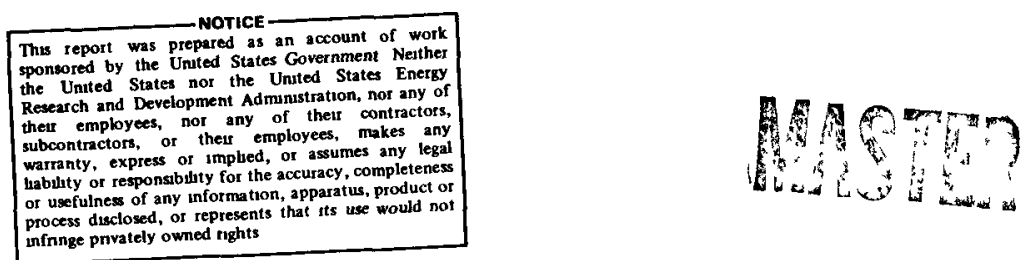

I. $\quad 0.00$

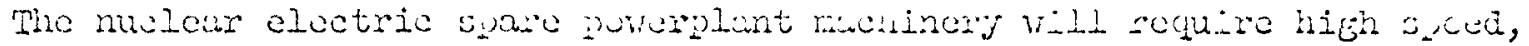

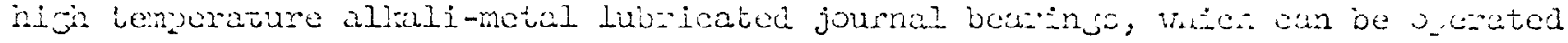

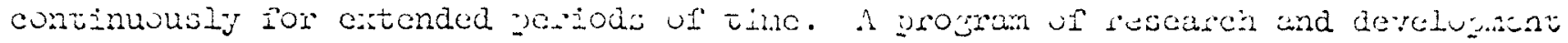

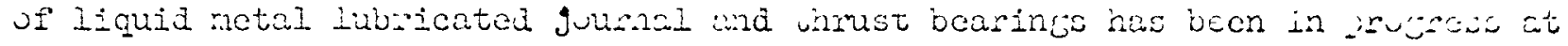

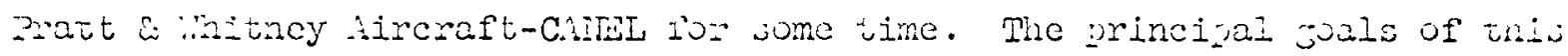

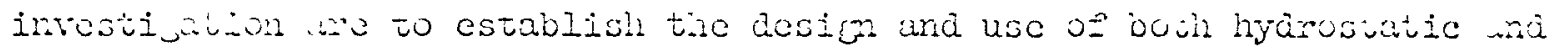
hydrodymande barings under oporazing conditions simulating s jace j,eration.

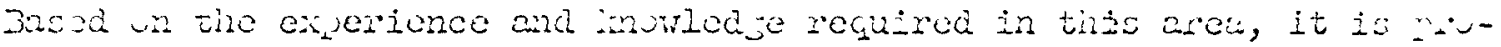

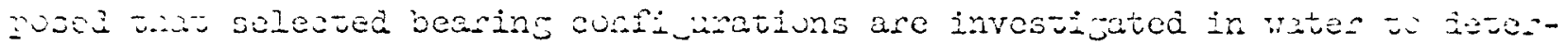

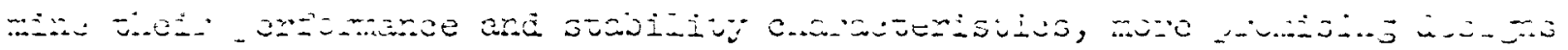

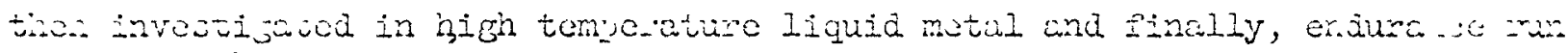

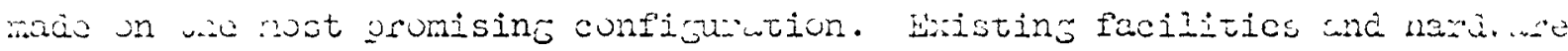

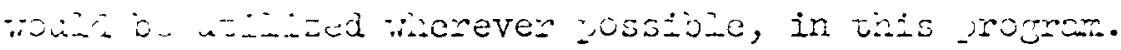

II. Pro $502 \div 20 m$

in waijtical and exporinental investigation of nigh specd, high tw. orture

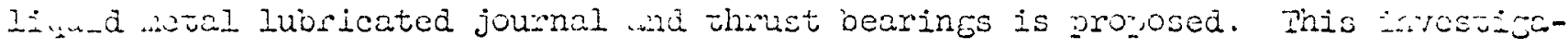
ino is a sused in three phases.

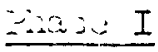

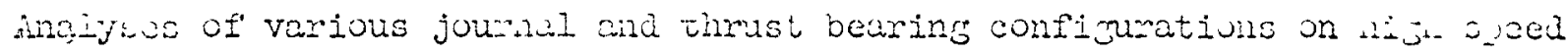

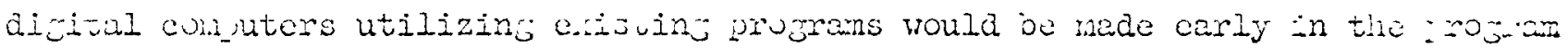

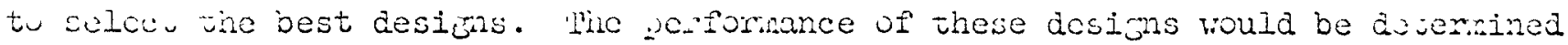
in tha single bearing ris at syeeds to 20,000 mon operating in both cold wid acaud water. Stability uf these bearings would then be furiter investivized in

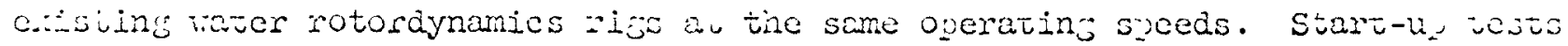
Wuila also be conffoted in the sotosdynamics rig. 


\section{Phace II}

Iiquid metal investigations, in single bearing tests and rotoriynamics rigs would follow the water tests on the most promising configurations determined from Phase I. The prescnt motor ariven single bearing liquid metal rig is capable of $10,000 \mathrm{rpm}$ and fluia temperatures of $1400^{\circ} \mathrm{F}$ with potassium or $\mathrm{NaK}$ and $1000^{\circ} \mathrm{F}$ with litivium. Sinsle bearing unit now in fabrication will have 15,000 rpn capability. The liquid motal stainless steel rotordynamics riz, which is currently in design, will be capable of 15,000 rom and the same temperature ranges for the fluids. A reIractory metal loop of the same design, also would be fabricated to permit test operation at higher fluid temperatures. Stability and start-up tests would be conducted in the rotordynamics rig.

Piaso III

3ourance mus in liquid metal of the final journal and thrust bearing devion would be conducted for an extended period of 10,000 hours. F. refractory neval rig would be required for lithium for operation to $1600^{\circ} \mathrm{F}$ while potassium ansi in testus would be conducted in stainless steel rigs to $1400^{\circ} \mathrm{F}$.

III. Backsrounà ard Related Experience

Pratt \& Whitney Aircraft-CAIEI is currently conducting an extensive inrestiJution of iluid film bearings as part of the SNAP-50 program. Investigations of hydrostatic, hydrodynamic, and hybrid bearings are being conducted in both water and liquid metal in nine different test stands.

The performance and stability of each fluid film bearing configuration is estabished individually in water and liquid metal. The configurations shouing the most promise are then investigated in a rotordynamics rig where the nost exact environmental conditions of actual machine operation are simulated.

Ore turoine driven vater single journal test rig (Figure 1 ) is presently screening various bearing designs (Figures 2 inrough 5). Performance stabi.: 


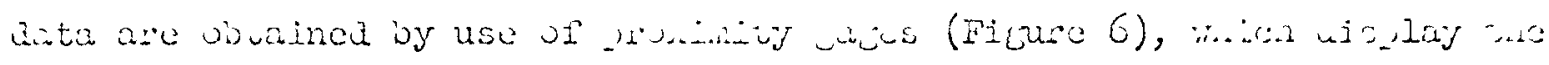

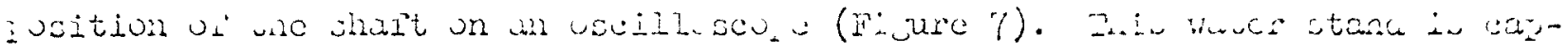
able of useating at $12,000 \therefore 3$.

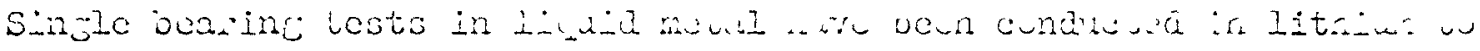

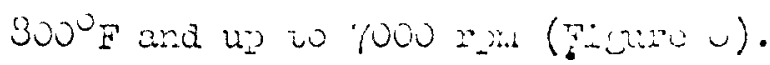

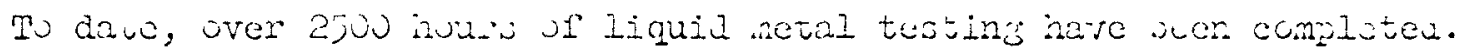

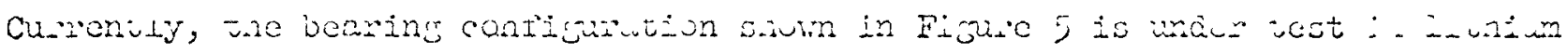

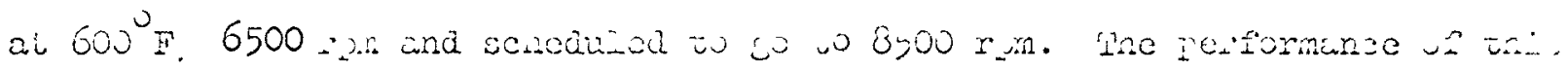

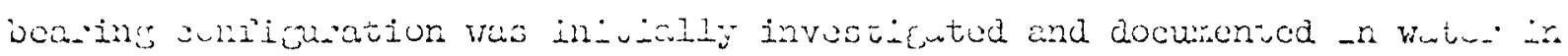
the siming tes unit suvin in Figure 1 .

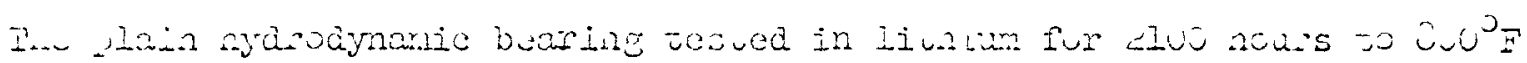

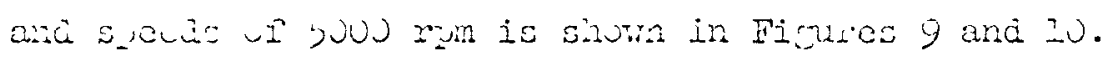

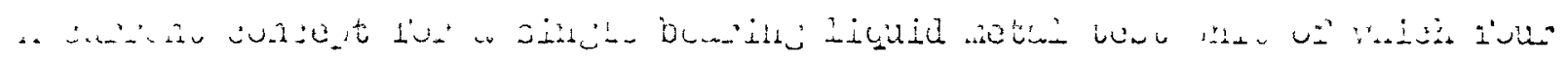
un-ua wo nut in fabsicariun is scom is Figure li. This desim, wizh ine test

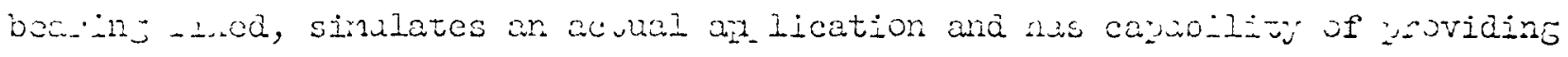

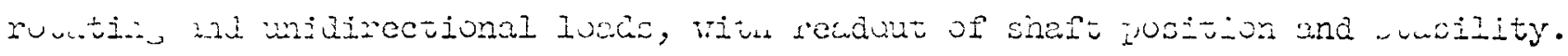

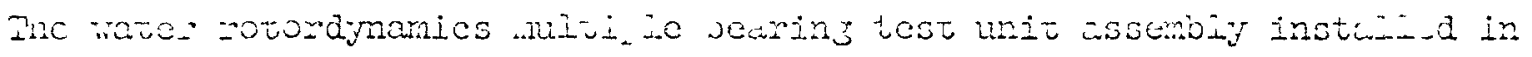

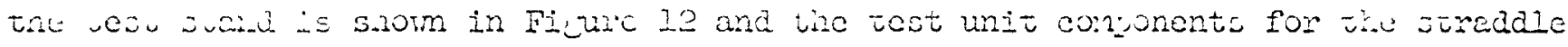

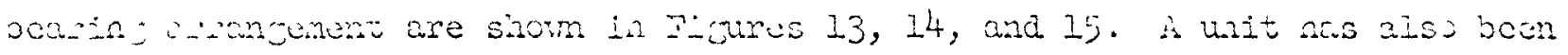

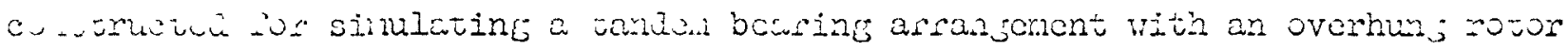
m... 


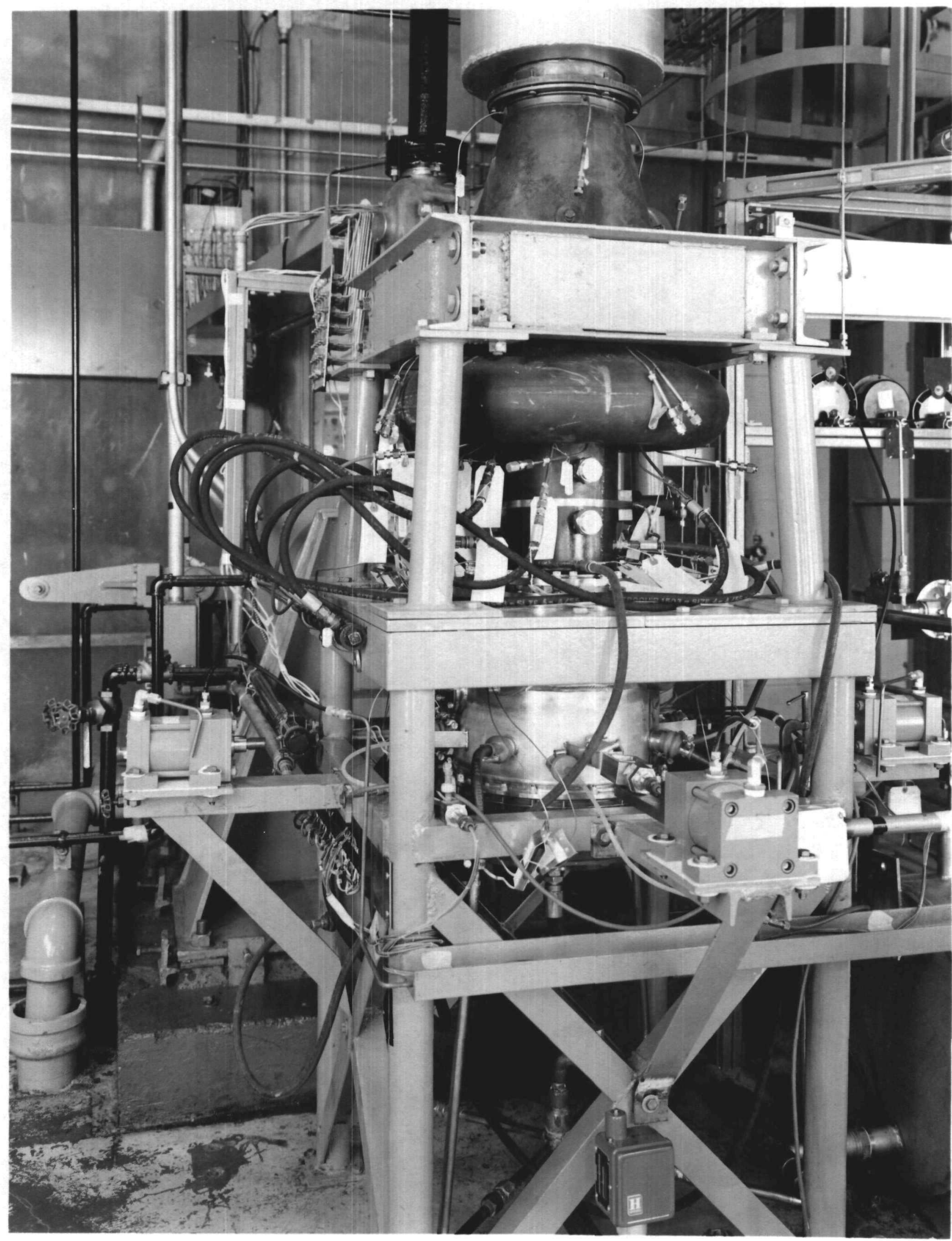




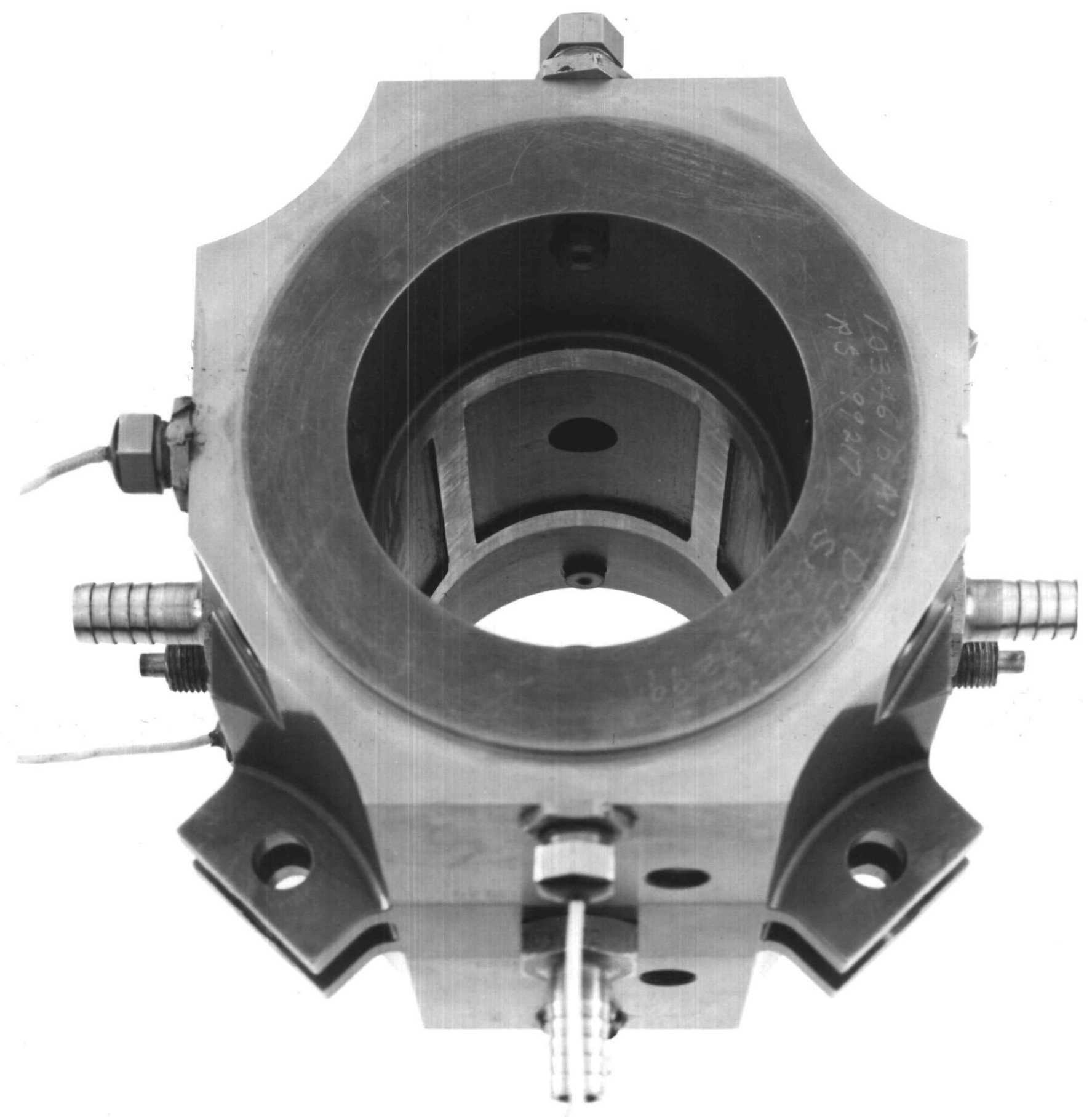

HYdRostatic Bearing \# 1034616-DCO \# 4765-3847 


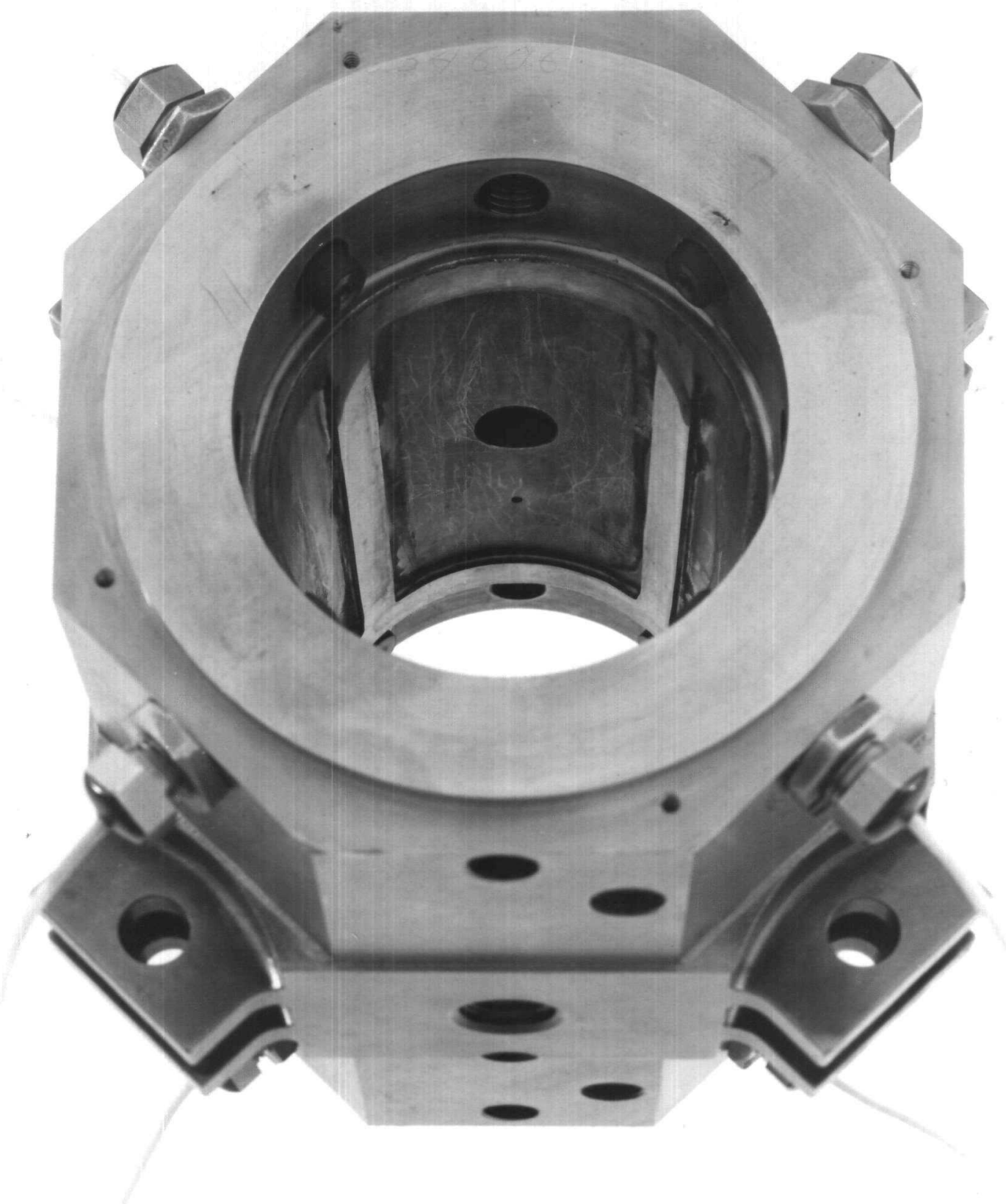

Hydrostatic Bearing \# 1034617-DCO \# 4492-3700-44874488 
Fis 4

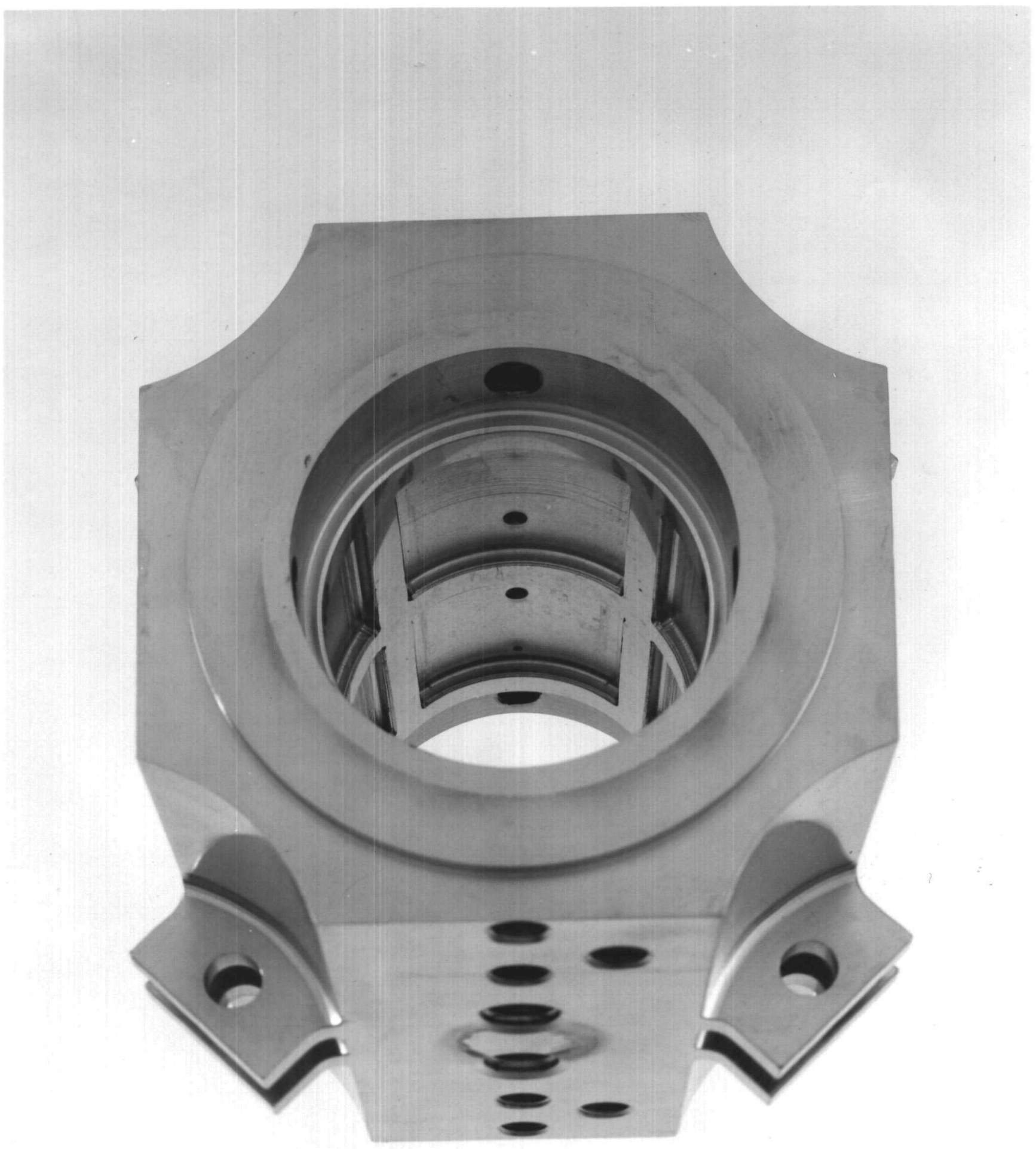

Hydrostatic Bearing \# 1034606-DCO \#3845-4761-47794639

$C-12893$ 


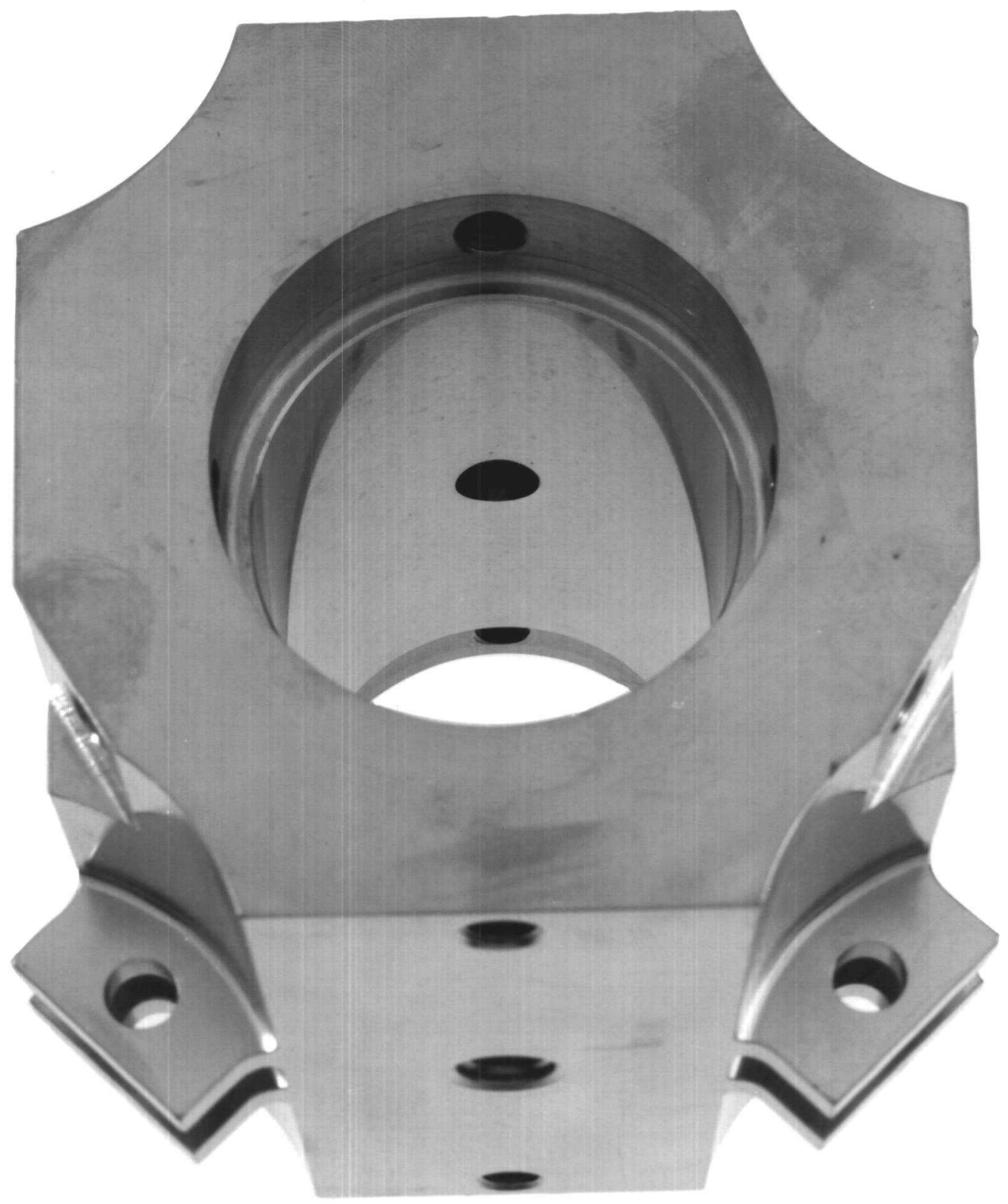

HYDRODYNAMIC BEARING \# 1034605-DCO \# 3845-4774

$$
C-12888
$$



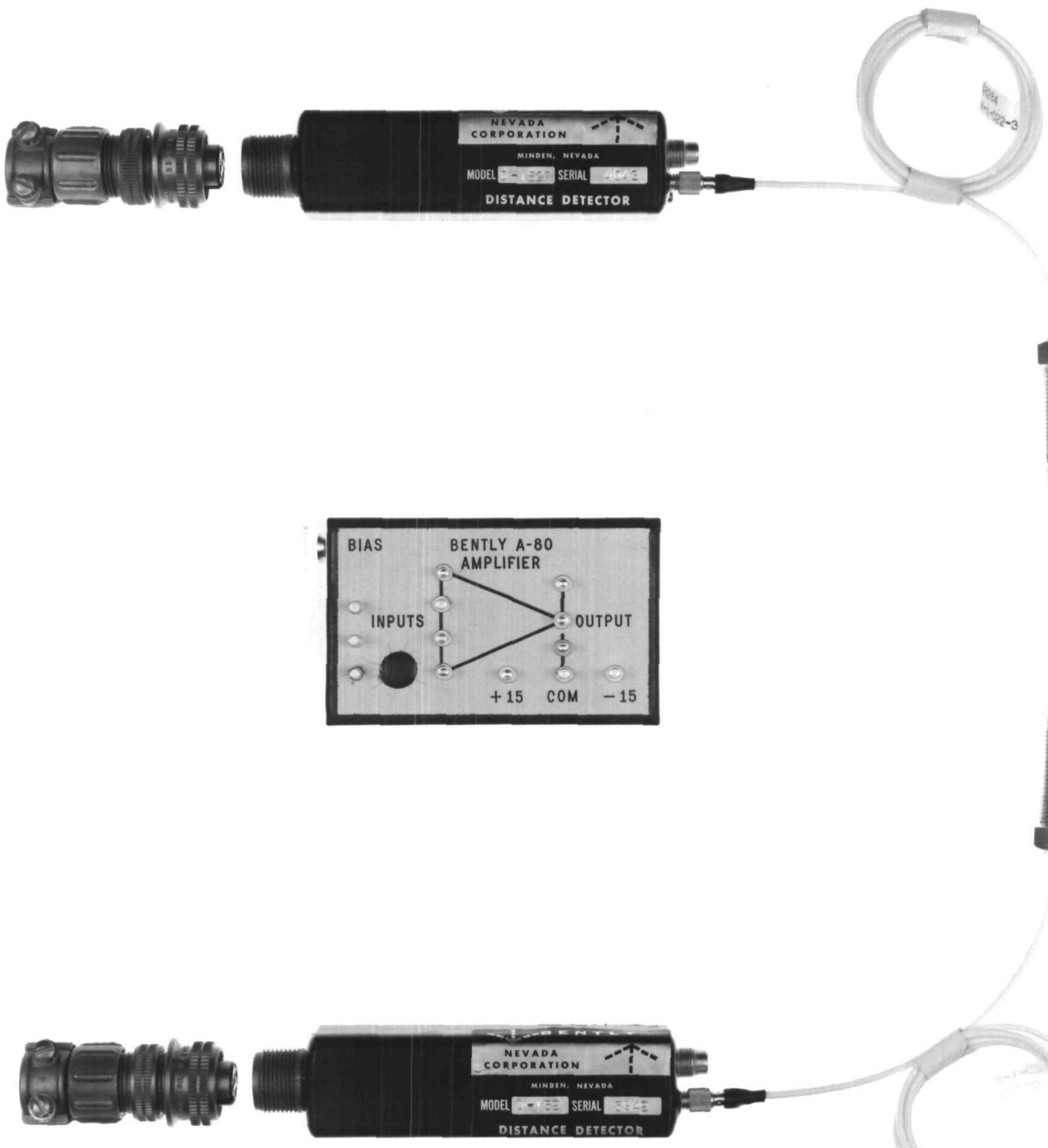

C -12926

3-3-64 
OSCILLCSCUPE TRACES CF BEARING ECCENTRICITY FOR HYCROSTATIC WATER BEARING

SHAFT SPEED - 4000 RPM

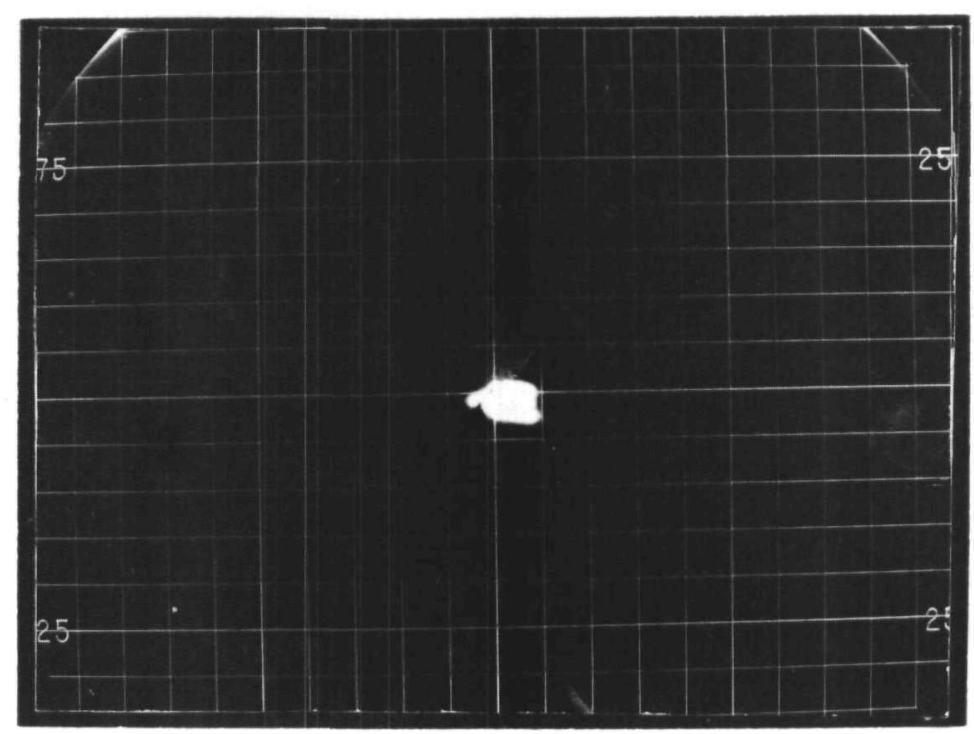

LOAD: O POUNDS DISPLALEMENT: $0 \mathrm{INCH}$

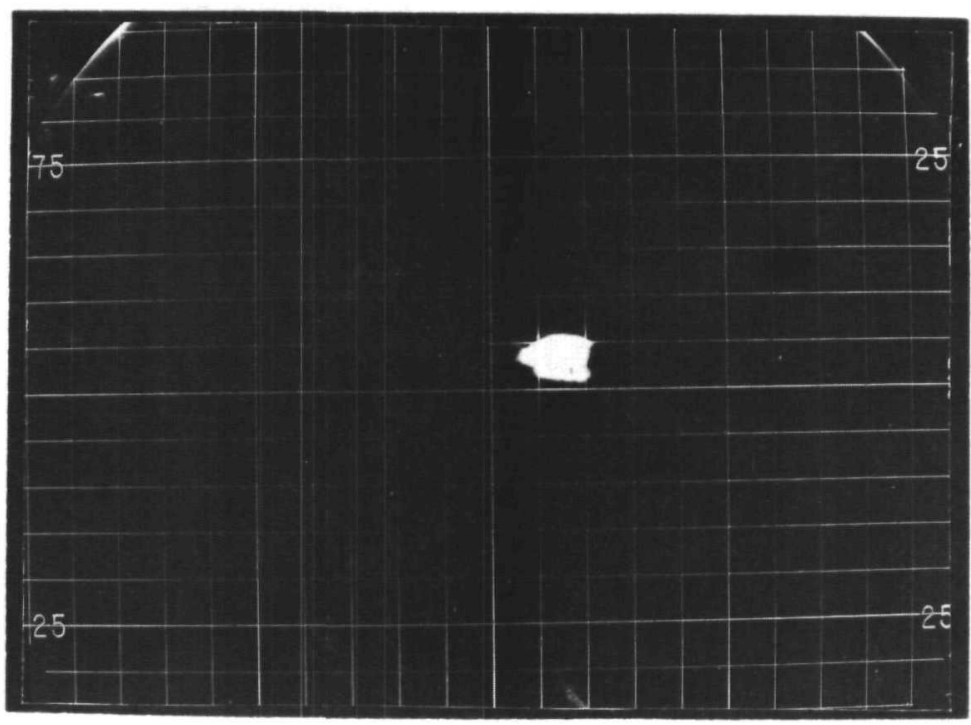

LOAD: 60 POUNDS DISPLACEMENT: $0.0002 \quad \mathrm{INCH}$ 


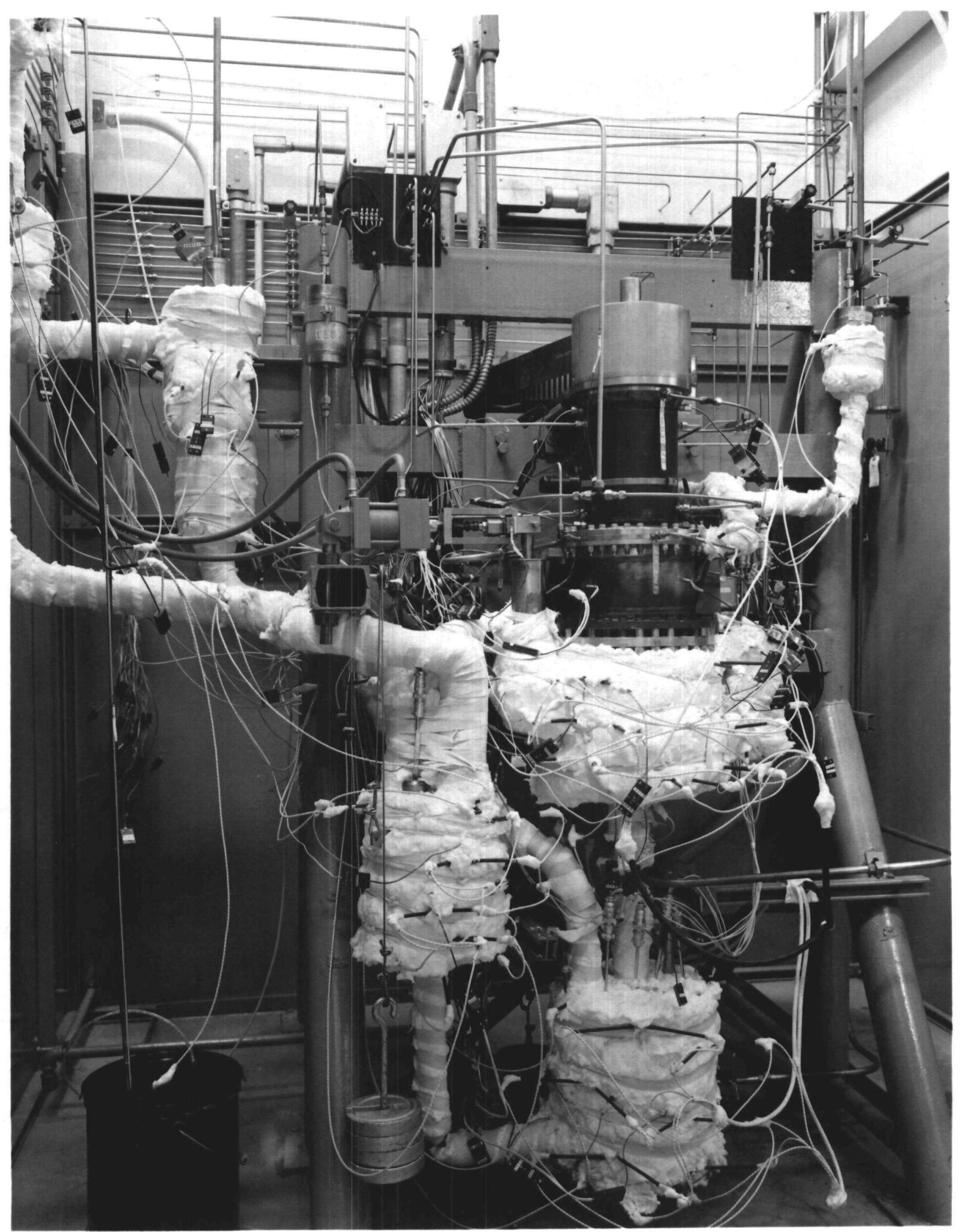

$E-10738$

3-12-63 


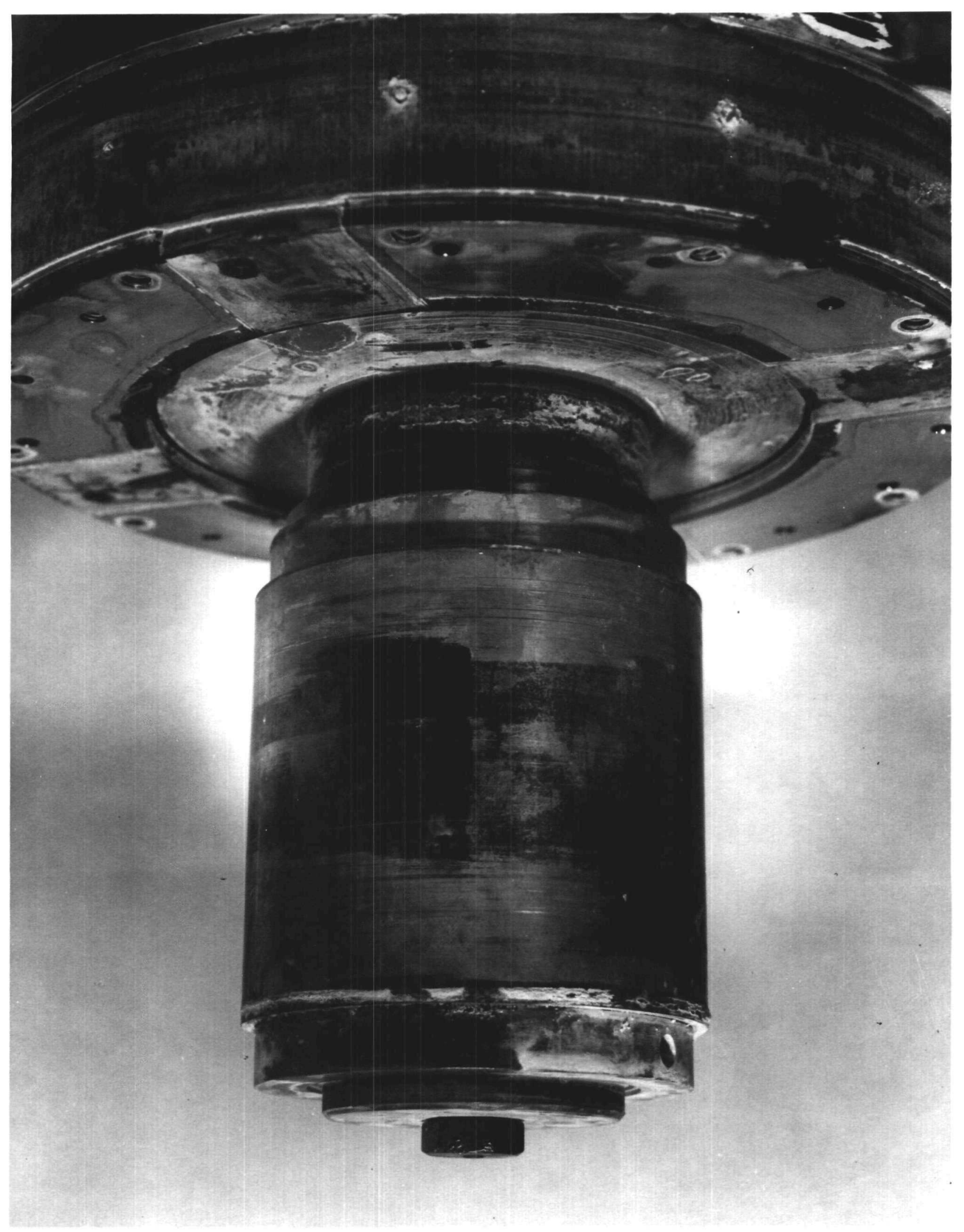




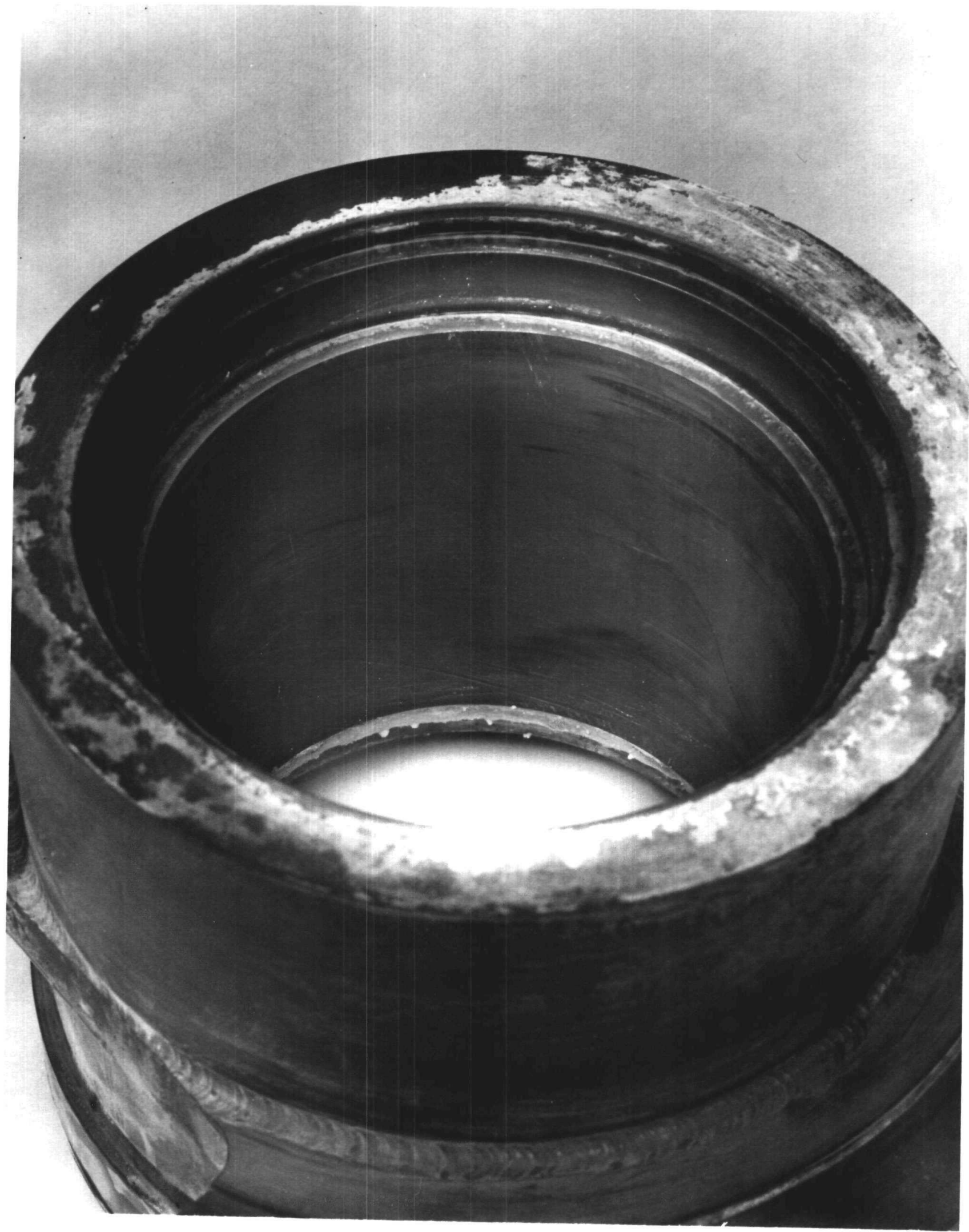

4F-4448

7-9-63 


\section{MODIFIED SINGLE JOURNAL BEARING}

\section{LIQUID-METAL TEST UNIT}

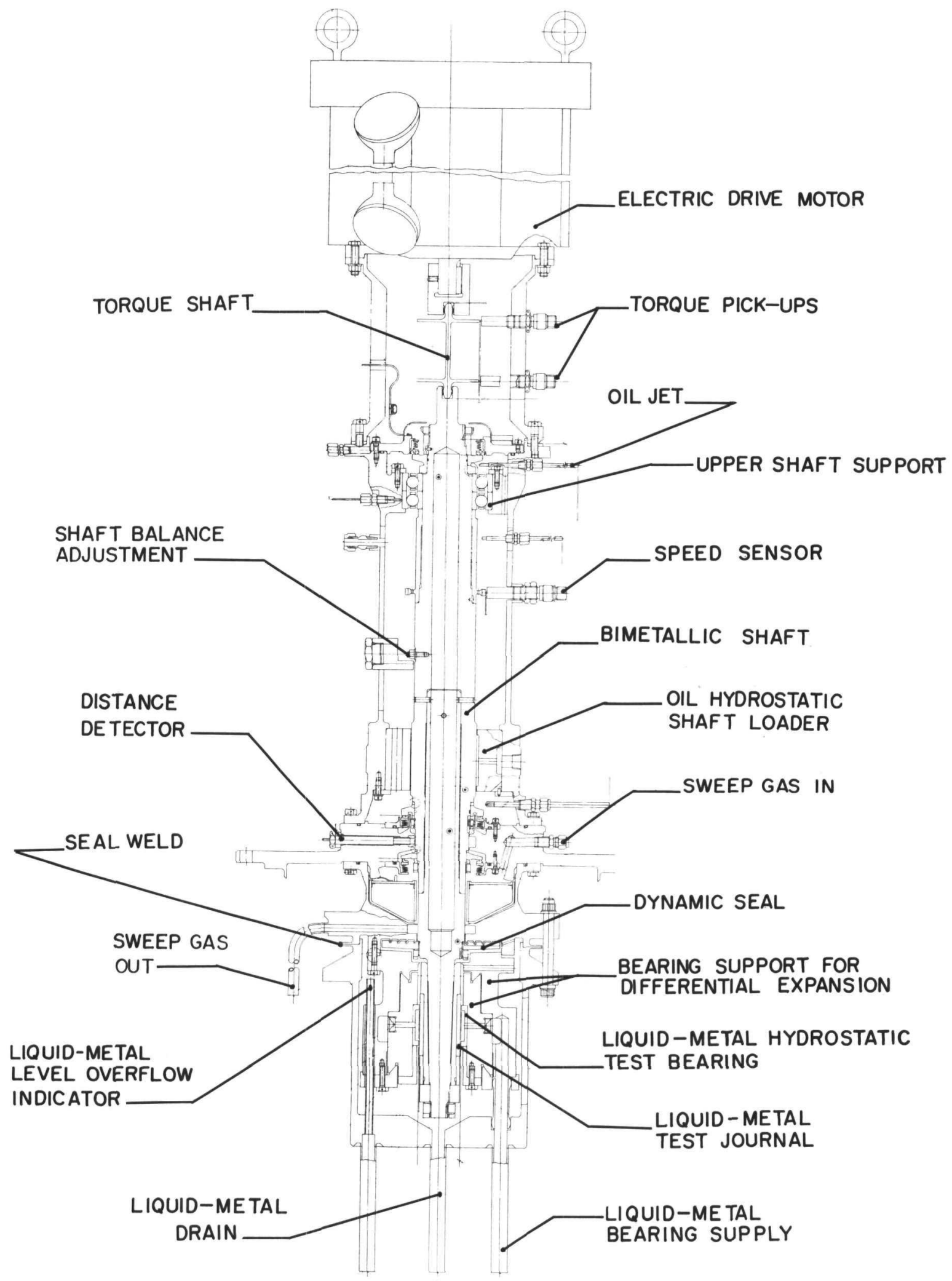




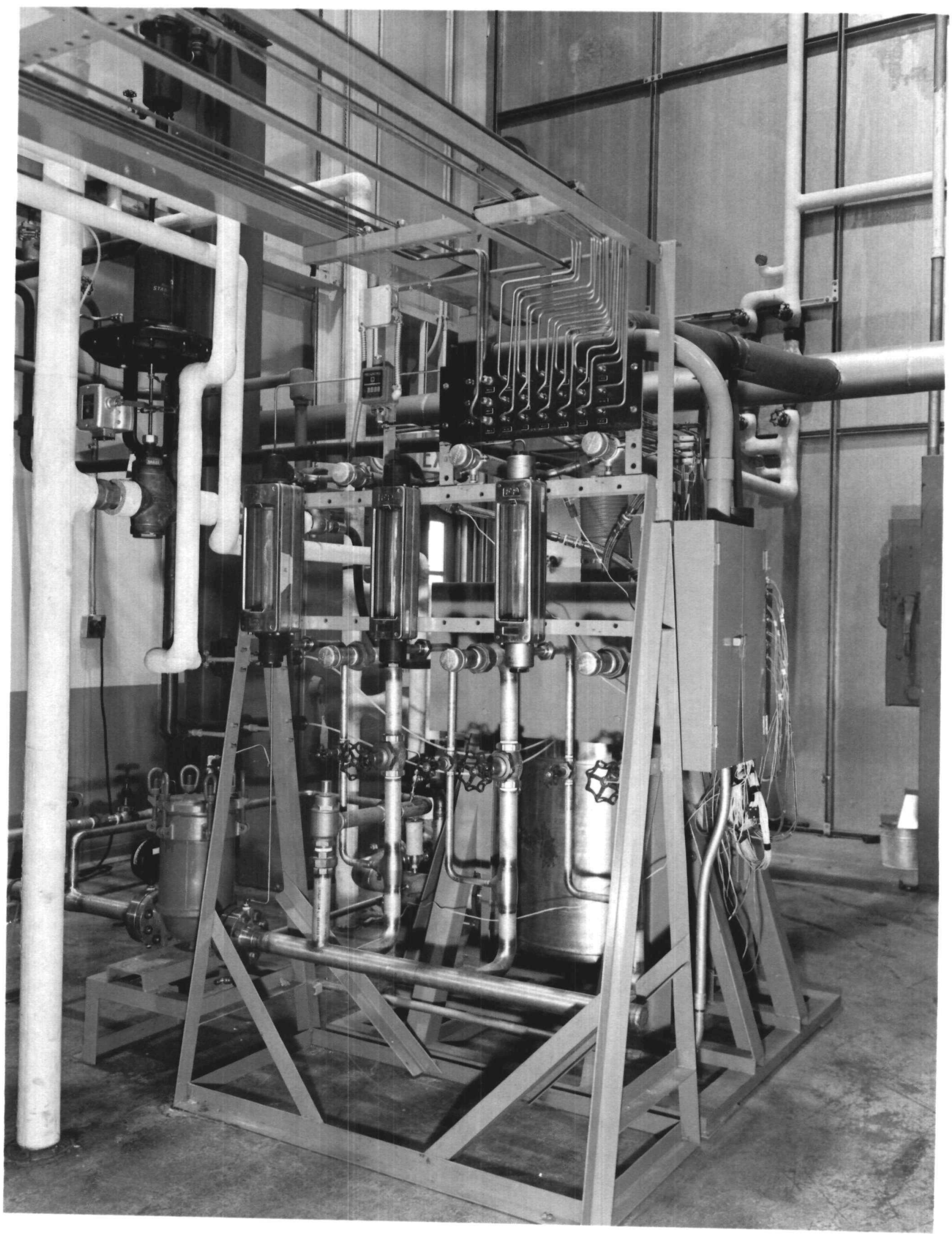


Fig 13

का

N

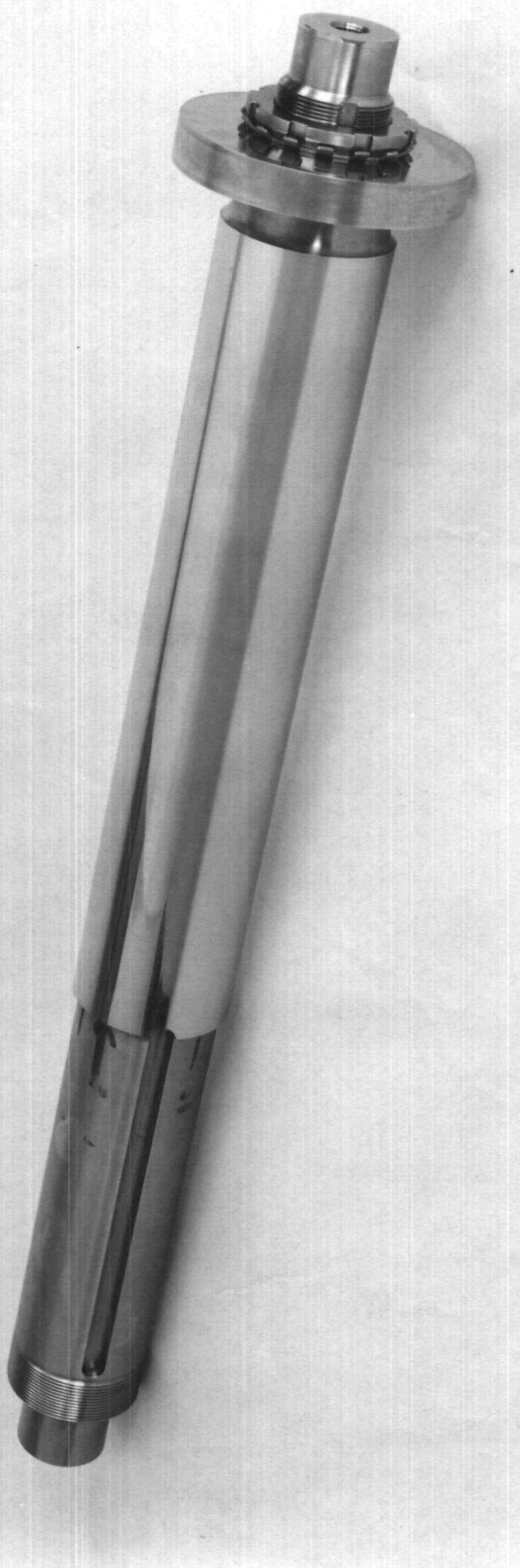

N

- 1 
ROTATING ASSEMBLY FCR ROTOR GYNAMICS STRADDLE BEARING WATER TEST UNIT

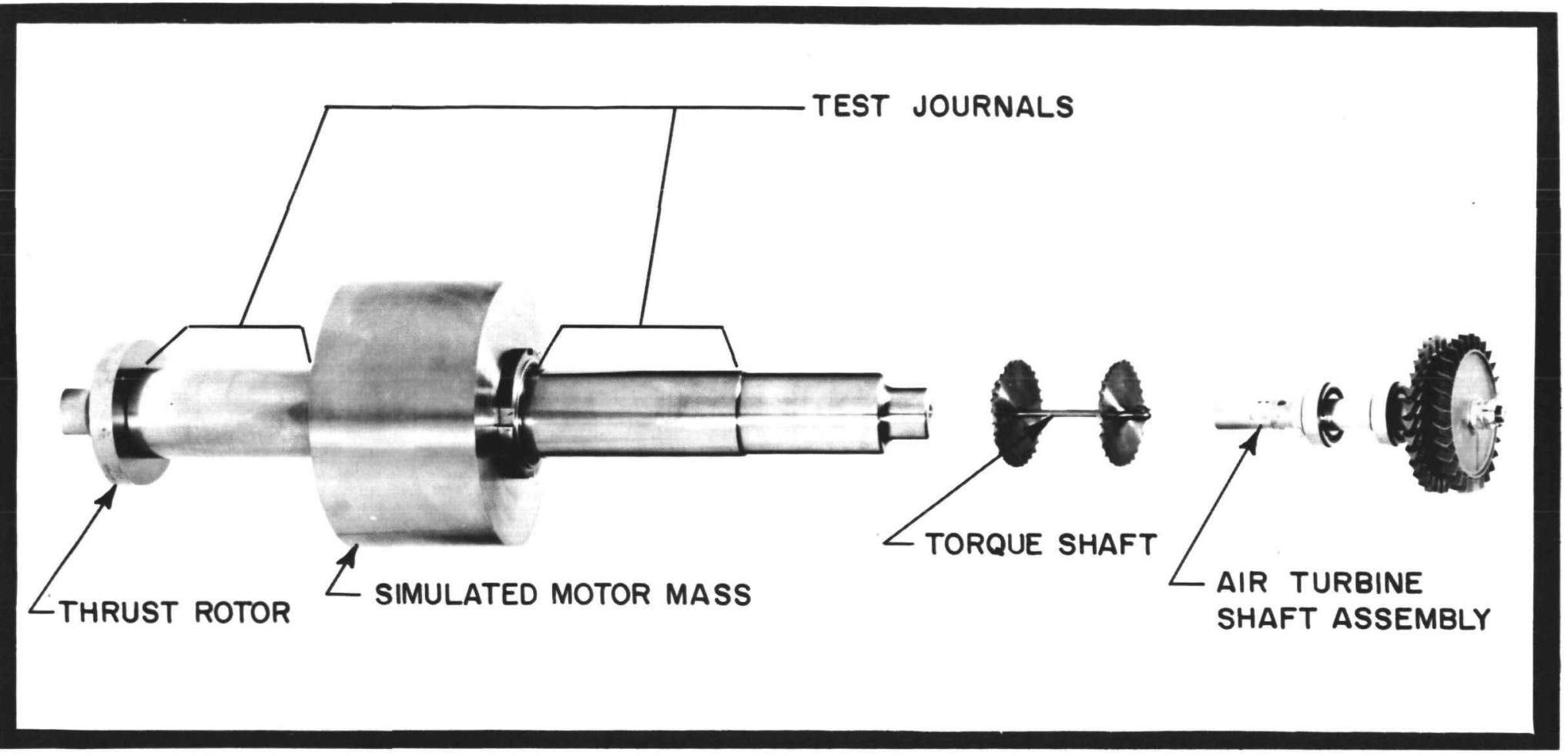


HOUSINGS FOR ROTOR DYNAMICS STRADDLE BEARING WATER TEST UNIT

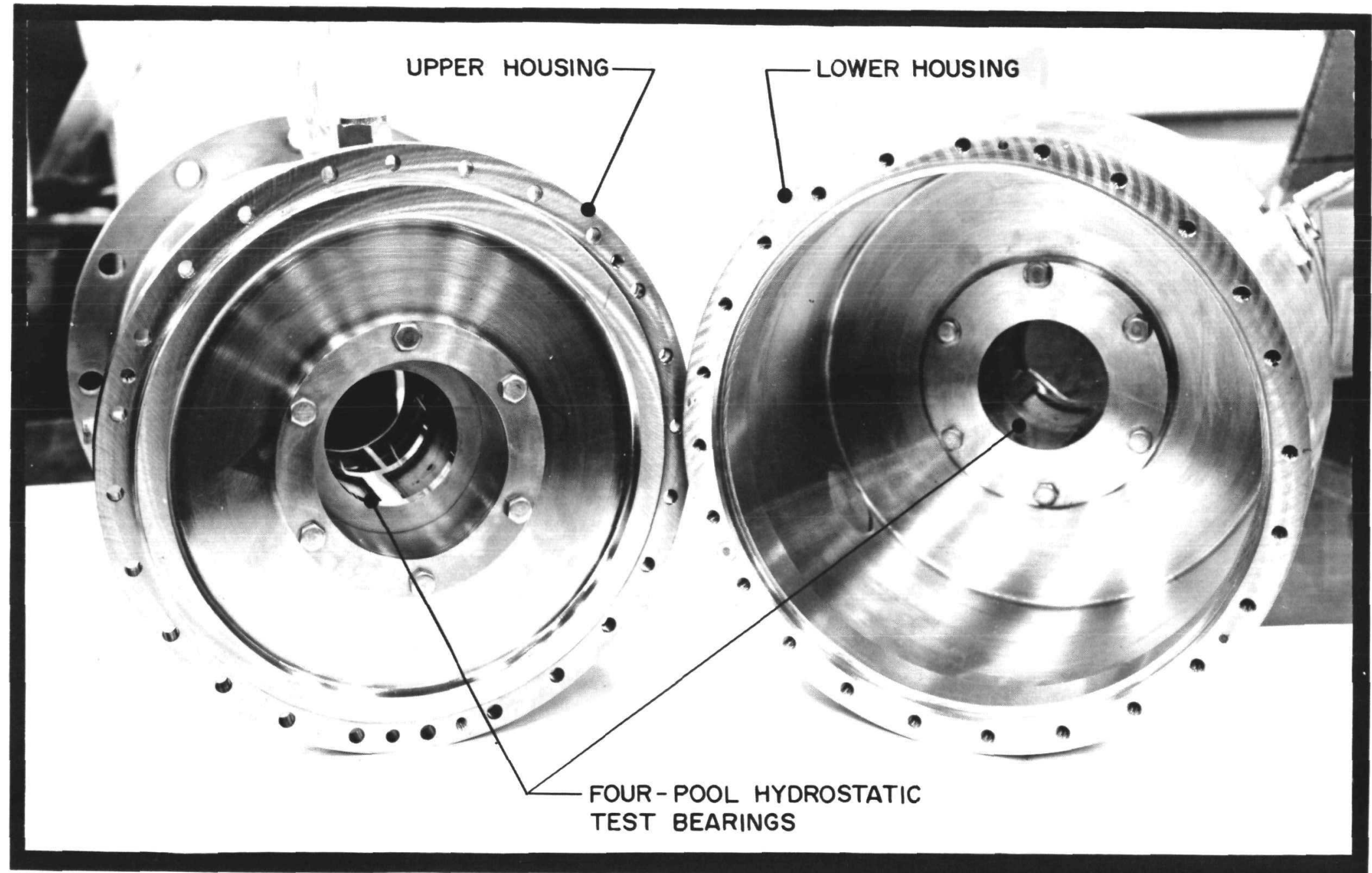

